\title{
Comparison of household expenditure between urban slum and non-slum dwellers in a Southwestern metropolis, Nigeria
}

Taiwo A Obembe ( $\nabla$ tobembe@cartafrica.org )

University of Ibadan https://orcid.org/0000-0001-9610-1137

Jonathan Levin

University of the Witwatersrand

Sharon Fonn

University of the Witwatersrand

Research article

Keywords: Slum dwellers, urban poor, household expenditure, urbanization, food expenditure, catastrophic health expenditure

Posted Date: August 21st, 2020

DOI: https://doi.org/10.21203/rs.2.13973/v2

License: (c) (1) This work is licensed under a Creative Commons Attribution 4.0 International License. Read Full License 
The authors have withdrawn this preprint from Research Square 